\title{
Comparative Analysis of Woody Species Diversity and Abundance in Mount Duro Natural Forest and Adjacent Agricultural Landscape, Nagelle Arsi, Oromia, Ethiopia
}

\author{
Mengistu Teshome ${ }^{1} \quad$ Gemedo Dalle ${ }^{2 *}$ Zebene Asfaw $^{3}$ \\ 1.Oda Bultum University, Department of Forestry, P. O. Box: 226, Chiro, Ethiopia \\ 2.Center for Environmental Science, College of Natural Sciences, Addis Ababa University, Ethiopia \\ 3.Hawassa University, Wondo Genet College of Forestry and Natural Resources, P. O. Box: 128, Shashamene
}

\begin{abstract}
The rich biodiversity of Ethiopia has been under threat because of vast and continued deforestation and agricultural expansion into forest ecosystems. This study was conducted to determine impacts of agriculture on biodiversity using comparative study of woody species diversity in natural forest and crop field and also by comparing population structure of woody species of the two different land use types. Random and systematic sampling techniques were to collect data on all indigenous woody species (Tree/shrub) from a total of 42 sample plots in crop field and natural forest. Sample plots were laid along three transect lines. All woody species in these plots were recorded and their Diameter at Breast Height was measured with tree caliper at $1.3 \mathrm{~m}$ above ground. Data on seedlings and saplings was collected from five subplots of $5 \mathrm{~m} \times 5 \mathrm{~m}$ located at the four corners and center of the main plot. Data was analyzed using descriptive statistics. Shannon diversity index and species richness were employed to determine diversity in the two land uses. A total of 48 indigenous woody species belonging to 43 Genera and 27 Families were recorded and identified from both crop field and natural forest. Fabaceae was the most diverse family followed by Rosaceae and Rubiaceae. Natural forest had higher number of species (41) than the crop field (27). The mean Shannon diversity index in the natural forest was significantly higher than that in the crop field. Natural forest had more species diversity and more density and importance value index of woody species. Therefore, it was concluded that unregulated expansion of agriculture into forest land should be reversed and local authorities and all concerned institutions should work together for sustainable management of forest biodiversity while still promoting agricultural productivity through from existing farm lands using technologies and other necessary inputs.
\end{abstract}

Keywords: Woody Species, Diversity, Crop Field, Population Structure, Natural Forest

DOI: $10.7176 / \mathrm{JNSR} / 9-15-02$

Publication date: August $31^{\text {st }} 2019$

\section{Introduction}

Ethiopia is an important centre of origin and diversity for many Flora and Fauna characterized by having rich endemic species (Berhan 1991; Sayer et al. 1992; FAO 2002; IBC 2009). A wide ranges of ecological, edaphic factors and climate conditions that account for the huge diversity of its biological resources both in terms of flora and fauna wealth; between 6500 and 7000 higher plant species, out of which about 19 percent are endemic to Ethiopia (Kelbessa et al. 1992; Shibru and Martha 1995; IBC 2009; Kebede et al. 2012). However, the relatively early and vast deforestation as a result of agricultural expansion in Ethiopia has led to severe depletion of natural forests, loss of biodiversity, impoverishment of ecosystems and land degradation (Tolera et al. 2008). A study on the pattern and magnitude of deforestation in the South Central Rift Valley Region of Ethiopia estimated that the total natural forest loss between 1972 and 2000 was about 40,000 ha, which is over $80 \%$ of the original forest cover that was present in 1972 (Dessie and Christiansson 2007; Dessie and Kleman 2007). The main driving forces behind deforestation were expansion of agricultural land, over exploitation of forest resources, overgrazing and establishment of new settlements into forested land coupled with increasing population pressure (Senbeta and Denich 2006; Dessie and Kleman 2007; Tolera et al. 2008; Kebede et al. 2012). Lemenih (2004) found that deforestation of the tropical dry Afromontane forest endangered the native forest biodiversity, not only through the outright loss of habitat but also by deteriorating the soil seed banks.

Though agricultural expansion is thought as proximate cause for the loss of biodiversity, there are variations among agricultural landscapes in their attributes that affect biodiversity (Harvey and Harber 1999). As an example, mono-cropping agricultural practices are likely to have low species diversity even as a few traditional agricultural systems common to the tropics include a remarkable diversity of plant species. These diversified traditional agricultural systems were reported to be better buffered against disturbances such as drought or pest outbreaks (Power and Flecker 2001).

Various agricultural landscapes in different parts of Ethiopia are characterized by high diversity of woody species and thus provide refugee for numerous woody species (Hamito and Abate 1994; Asfaw and Hulten 2003) and maintaining biological diversity (Nikiema 2005; Schelas and Greenberg 1996). Further to its biological 
diversity conservation, these woody species on agricultural landscapes have economic and visual contribution to the landscape (FAO 2002; Boutin and Martin 2008; Ma 2006). However, a continuous cultivation of agricultural land, especially crop fields has influences on the woody diversity and population structure through deteriorating soil seed banks which hampered regeneration potential of woody species (Tolera et al. 2008; Lemenih and Teketay 2006). Research on forest and agricultural landscape had been made in different parts of the Ethiopia considering the comparison of soil property changes under woody crop field and natural forest, other land use types (Lemenih et al. 2004; Lemenih 2004; Getachew et al. 2012). However, comparative studies between natural forest and cop fields using woody species diversity and Importance Value Index (IVI) were limited and no data was available for Gara Duro Mountain Ecosystem. Therefore, the aim of the present study was to conduct comparative study of woody species diversity and abundance in natural forest and adjacent agricultural land (i.e crop fields).

\section{Material and Methods Site description}

The study was conducted in Nagelle Arsi District of West Arsi Zone, Oromia, Ethiopia from January to February, 2014. The study site lie between $7^{\circ} 16^{\prime} 40^{\prime \prime N}-7^{\circ} 20^{\prime} 20^{\prime \prime} \mathrm{N}$ latitude and $38^{\circ} 45^{\prime} 20^{\prime \prime E}-38^{\circ} 49^{\prime} 20^{\prime \prime E}$ longitude and located about 240km south of Addis Ababa (Fig.1) and $18 \mathrm{~km}$ from Nagelle Arsi town to east. The crop field under study covers four rural kebeles such as Lephis, Gambelto, Ashoka and Bombaso Rejji which are close to Mount Duro natural forest around Lephis, which belongs to Nagelle Arsi Wild life and forest enterprise, Gambo district and part of the Shashemenne-Munesa National Priority Forest Area of Ethiopia.

The portions of the natural forest under this study lie at the altitudes from 2080 to 2552 masl. The scattered woody species in crop field was retained from the clearance of natural forest as result of agricultural expansion (Tolera 2006; Lemenih 2004). The soils parent materials consist of volcanic lavas, ashes and pumices from quaternary volcanic activities in the Rift Valley. Soil type of the study area was classified as Mollic Andosol (FAO 1980).

The rainfall in the area has bimodal distribution. The mean annual rainfall is $1200 \mathrm{~mm}$ and the annual mean temperature is about 200C (FAO 1980). The total area of the District was about $1396 \mathrm{~km} 2$ of which $52 \%$ is arable, $30 \%$ water bodies, $5 \%$ forest and 13\% grazing. Nagelle Arsi is characterized by crop-livestock based farming systems (Lemenih et al. 2004). The district had a total population of 260,129 in 2007. The population density of the district was 185.7 persons per $\mathrm{km} 2$ (CSA 2007).

\section{Vegetation Data Collection and Sampling Design}

To gather all woody species a total of eighty four sample plots was used for each land uses. Systematic sampling design was used to arrange the plots with three parallel transect lines in each crop fields and natural forest (Fig.2.a, b). In crop field plot size of $50 \mathrm{mx} 100 \mathrm{~m}\left(5000 \mathrm{~m}^{2}\right)$ was laid down along transect lines which arranged at a distance of 300 meters. A large plot size in crop field is due widely scattered or dispersed and has low tree density. Each transect line was $6 \mathrm{~km}$ long and the distance between consecutive transect lines was $1.5 \mathrm{~km}$.

While, in natural forest three parallel transect lines were laid down from the peak of the mountain down to the base having different number of plots depending on the length of the transect lines at the interval of $500 \mathrm{~m}$. The transect lines were arranged parallel to each other throughout entire natural forest and a total of forty two sample plot size of $20 \mathrm{~m} \times 20 \mathrm{~m}\left(400 \mathrm{~m}^{2}\right)$ was used (Austin 2005; Senbeta and Denich 2006; Gurmessa et al. 2013). Within main plots at four corners four sub-plots and in the center one sub-plot of $5 \mathrm{~m} \times 5 \mathrm{~m}$ was laid for shrub species. Within main plots at four corners four sub-plots and in the center one sub-plot of $5 \mathrm{~m} \times 5 \mathrm{~m}$ becomes laid for shrub species. The distance between two plots were adjusted at $100 \mathrm{~m}$ along transect line to minimize diversity variation among plots.

For each land uses in every plot, all woody species (Trees and shrubs') had been identified and diameter at breast height (DBH) for all woody species $\geq 2 \mathrm{~cm}$ at $1.3 \mathrm{~m}$ was measured. For woody species forked below 1.3 meters, individual stems were separately measured and then average dbh was taken. The diameter has been measured using caliper. Diameter tape was used at times when the trunk of the trees to be measured exceptionally exceeded $65 \mathrm{~cm}$. The entire lists of all woody species had been made for each sample plot throughout the entire area under examine and recorded by local name (Afaan Oromoo) and specimens had been collected, pressed and dried properly in the field. Specimen identification and documentation have been made at the National Herbarium of (ETH), Addis Ababa University.

\section{Data analysis \\ Diversity and similarity indices}

The species diversity on crop fields and natural forest were estimated using species richness, Shannon diversity index, Simpson diversity index and Fisher's $\alpha$ (alpha) and Shannon evenness (Krebs 1999; Magurran 2004) by InfoStat free software. Simpson and Shannon indicators are showing the heterogeneity. Simpson index had been used to measure evenness. Values of Shannon diversity indices of the two land use system were compared using 
one way ANOVA by implementing SAS software package, version 9.1

\section{Analysis of population structure}

Important (IVI) woody species was used to compute the population structure of woody species in both natural forest and crop fields.

$$
\begin{aligned}
& \text { Frequency }(\%)=\frac{\text { Number of quadrats in which t he species occurres }}{\text { Total number of quadrats studied }} * 100 \\
& \text { Relative frequency }(\%)=\frac{\text { Numberof occurenceof the species }}{\text { Numberof occurenceof allspecies }} * 100 \\
& \text { Relative dominance }(\%)=\frac{\text { Total basal area of species }}{\text { Total basalarea of all the species }} * 100 \\
& \text { Relative abundance }(\%)=\frac{\text { in all quadrats number of individual s of a species }}{\text { Total number of quadrats in which the species }} \\
& \text { occured }
\end{aligned}
$$

$\mathrm{BA}=\frac{\prod \mathrm{D}^{2}}{4}$

Where, = basal area $\left(\mathrm{m}^{2}\right), \mathrm{dbh}=$ diameter at breast height $(\mathrm{cm}) ; \pi=3.14$

Importance Value Index (IVI) = Relative abundance + Relative dominance + Relative frequency) (Curtis 1959; Kent and Coker 1992).

\section{Results}

Woody species diversity and similarity in species composition

A total of 48 indigenous woody species belonging to 43 Genera and 27 Families were documented from both crop field and natural forest. Overall, Fabaceae was the most diverse family followed by Rosaceae and Rubiaceae. The crop field had 27 different woody species that belonged to 20 families. Similarly, from Mount Duro natural forest, 41 different woody species were recorded that belonged to 26 families (Appendix 1).

Similarities in woody species composition are expected between the natural forest and crop fields. On the woody species recorded, 20 (41.7\%) were common to both crop field and natural forest. The study showed that 21 $(43.7 \%)$ and 7 (14.6\%) species were found only in natural forest and crop field, respectively (Appendix 1).

The Mean Shannon diversity index was significantly higher in natural forest $(\mathrm{P}<0.05)$, which indicating greater diversity of species in natural forest (Table 1). The Simpson index of diversity (1-D) for woody species was also relatively higher in the natural forest $(0.880)$ than in the crop field $(0.8367)$. Species evenness in the crop field was slightly higher (0.709) than in the natural forest $(0.671)$. On the other hand, Fisher's alpha showed high value for the natural forest and low value for the crop field (Table 1).

\section{Comparative study of Species Abundance in the Natural Forest and Crop Field}

Croton machrostachyus, Vernonia myriantha, Maesa lanceolata, Bersama abyssinica and Podocarpus falcatus were top five species with the highest density (number of individual species per hectare) in the natural forest. On the other hand, density of woody species in the crop field was the lowest (Table 3) but still Croton machrostachyus and Podocarpus falcatus were important species on crop field. Further comparative study using Importance Value Index (IVI) showed that Podocarpus falcatus, Croton machrostachyus, Vernonia myriantha, Bersama abyssinica, Maesa lanceolata, Teclea nobilis, Maytenus, Juniperus procera, Vangueria madagascariensis, Polyscias fulva were top ten important woody species in the natural forest (Table 3). On the other hand, Croton machrostachyus, Podocarpus falcatus, Prunus africana, Vernonia amygdalina, Erythrina brucei, Vernonia myriantha, Ficus sur, Celtis africana, Ekebergia capensis and Acacia seyal were top ten important woody species in crop fields (Table 2). Podocarpus falcatus and Croton machrostachyus were abundant species both in natural forest and agriculture landscape.

\section{Discussions}

\section{Woody Species Diversity and Similarity in Species Composition}

Natural forest had more species diversity and more density and importance value index of woody species explaining that fact that unregulated agricultural expansion into forest land had negative impact on woody species diversity and abundance. This study determined that Podocarpus falcatus, Croton machrostachyus, Vernonia 
myriantha, Bersama abyssinica and Maesa lanceolata had highest Importance Value Index in the natural forest. It was worth noting that there were slight difference in botanical composition of dominant woody species in the same forest as previous study by Gemedo Dalle (2015) showed that Podocarpus falcatus, Maytenus senegalensis, Myrsine melanophloëos, Ficus sur and Arundinaria alpina, were the five leading dominant species in the forest. The importance value index is useful to compare the ecological significance of species (Lamprecht 1989) as it indicates the extent of dominance of a species in the structure of a forest stand (Curtis and McIntosh 1951). Therefore, this study determined that Podocarpus falcatus, Croton machrostachyus, Vernonia myriantha, Bersama abyssinica and Maesa lanceolata in the natural forest, and Croton machrostachyus, Podocarpus falcatus, Prunus africana, Vernonia amygdalina and Erythrina brucei in the crop fields were dominant species with high ecological significance in their respective landscapes.

The mean Shannon diversity index in the natural forest was significantly higher than that in the crop field. The result was in agreement with previous reports. For example, Nikiema (2005) reported that crop field had lower Shannon diversity index than natural forest but, there was no significant difference in evenness index.

The low species richness in crop fields may lead to the assumption that the shrubs which represent the understorey of the natural vegetation have evidently been cleared during conversion of the natural forest to crop fields (Lemenih and Teketay 2006, Lemenih 2004; Tolera 2006; Tolera et al. 2008). Various studies (e.g. Tolera 2006 and Lemenih 2004) indicated that scattered woody species in crop field were retained from the clearance of natural forest as result of agricultural expansion.

The present result was in disagreement with the previous study by Tolera (2006) who reported almost similar woody species in the two land use systems: 32 on crop fields and 31 in the natural forest at Beseku (Nagelle Arsi) very close to the current study area. A continuous cultivation of crop fields deteriorates soil banks through hampering regeneration capacity and seedling recruitments (Lemenih and Teketay 2006; Tolera et al 2008).

There were more species in the natural forest with significant similarity between the two land use types. Similarity in species composition was due to the fact that scattered woody species in crop field were retained from the clearance of natural forest as result of agricultural expansion (Lemenih 2004; Tolera, 2006). Regeneration of young trees in crop fields was almost non-existent (Lemenih 2004; Tolera et al. 2008). Additionally, a continuation cultivation of crop fields hampered regeneration potential of soil seed banks (Lemenih and Teketay 2006).

\section{Woody Species Management on Agricultural Landscapes}

Although agriculture had negative impacts on diversity and density of woody species, still significant numbers of species do exist on agricultural landscapes calling for the need to consider these landscapes for conservation and sustainable utilization of agroforestry species. Conservationist had focused on the protection of natural forests and woodlands (Schelas and Greenberg, 1996) and did not give enough attention to the widely dispersed on-farm woody species. These patches are often critical components of a farmers' environment being a source of products and environmental services of importance to the farmers' livelihood and welfare. Recently, it has been recognized that woody species in these landscapes play an important role in maintaining biological diversity (Schelas and Greenberg 1996; Harvey and Haber 1999; Nikiema 2005). Harvey and Haber (1999) pointed out that remnant woody species retained in crop fields provide habitats and resources that are otherwise absent from agricultural landscapes and also serve as critical nesting, feeding, and roosting sites for a variety of bird and bat species.

The integration of woody species into crop fields has been proposed as one way of diversifying agroecosystems in a way that is beneficial to the environment and can maintain and perhaps enhance biodiversity (Sanchez et al. 1997). Besides, they could provide replenishment of soil fertility and marketable forest products. The relevant services of woody species are those that increase the crop yields (nitrogen fixation, increased soil organic matter content, nutrient cycling, soil conservation, etc.), create environmental resilience (niche diversification, food-web complexity, reduced greenhouse emissions through carbon sequestration, etc.) (Oumer Ejero, 2009).

The woody species also contribute to the enrichment of faunal biodiversity in the agricultural landscapes which are important for pollination. Therefore, in addition to regulating expansion of agricultural lands into forest ecosystems, conservation and sustainable utilization of woody species on-farm are critical for ensuring food security and healthy functioning of agricultural landscapes.

\section{Conclusion}

Natural forest had higher species diversity, density and importance value index of woody species than the crop fields. Such difference in both diversity and abundance of species was expected as agriculture has been among major threats to biodiversity. Therefore, it was concluded that unregulated expansion of agriculture into forest land should be reversed and local authorities and all concerned institutions should work together for sustainable management of forest biodiversity while still promoting agricultural productivity through from existing farm lands using technologies and other necessary inputs.

Furthermore, conservation and sustainable use of forest patch and trees and shrubs on farm lands is important 
for the healthy functioning of agricultural ecosystem. Integrated agroforestry systems need to be promoted as such integration contributes to biodiversity conservation, improves soil fertility, enhances nutrient cycling and diversify income for local farmers. Animals such as insects and birds are important for pollination services and the management of woody species on farm is directly related to increased habitats for these pollinators which in turn contribute to increased agricultural productivity.

\section{Aacknowledgments}

We would like to thank the Ethiopian Biodiversity Institute for its financial support to conduct this research work.

\section{References}

Asfaw, Z. \& Hulten, H. (2003). Tree diversity management in the traditional agroforestry land use of Sidama, southern Ethiopia. Acta Universitatis Agriculturae, SLU. SILVESTRIa. 263 (1): 1 - 28.

Austin, M. P. (2005). Vegetation and environment: discontinuities and continuities. In: van der Maarel E (eds): Vegetation ecology. USA, Blackwell publishing company. pp. 52-84.

Berhan, T. (1991). Diversity of Ethiopian Flora. In: Engels JMM, Hawkes JG, Melaku Worede (eds) Plant Genetic Resources of Ethiopia. Cambridge University Press. pp 75-81.

Boutin, C. \& Martin, P. (2008). Plant diversity in crop fields and woody hedgerows of organic and conventional farms in contrasting landscapes, Agric. Ecosys. Environ. 123:185-19.

CSA (Central statistical Agency). (2007). Population and Housing Census of Ethiopia: Statistical Report for Oromia Region; Part I: Population Size and Characteristics.

Curtis, J. T. (1959). The vegetation of Wisconsin: Univ. Wisconsi Press, Madison.

Dessie, G. \& Christiansson. (2007). Forest Decline in South Central Ethiopia: Extent, history and process. Doctoral dissertation, Department of Physical Geography and Quaternary Geology, Stockholm University, Sweden.

Dessie, G. \& Kleman. ( 2007). Pattern and Magnitude of Deforestation in the South Central Rift Valley Region of Ethiopia. Mountain research and development. 27(2): 162-168.

FAO (Food and Agriculture Organization). (2002). Role of Planted Forests and Trees Outside Forests in Sustainable Forest Management. Available at http://www.fao.org/docrep/009/j5838e/J5838E08.htm (Accessed on 19 July 2018).

Gemedo Dalle. (2015). Floristic Composition, Populations Structure and Conservation Status of Woody Species in Shashemenne-Munessa Natural Forest, Ethiopia. Ethiopian Journal of Biodiversity 1(1): 21-44.

Getachew, F., Abdulkadir, A., Lemenih, M. \& Fetene, A. (2012). Effects of Different Landuses on Soil Physical and Chemical Properties in Wondo Genet Area, Ethiopia. New York Science Journal: 5(11): 110-118.

Gurmessa, F., Soromessa, T.\& Kelbessa, E. (2013). Floristic Composition and Community Analysis of Komto Afromontane Moist Forest, East Wollega Zone, West Ethiopia. Science Technology Arts Research. Journal: 2 (2): 58-69.

Hamito, D. \& Abate, F. (1994). Forestry Research in directory. Forestry Research Centre, Addis Ababa.

Harvey, C. A. \& Haber, W. A. (1999). Remnant Trees and the Conservation of Biodiversity in Costa Rican pastures. Agroforestry Systems 44: 37-68.

IBC (Institute of Biodiversity Conservation). (2009). Ethiopia's $4^{\text {th }}$ Country Report to Convention on Biological Diversity. Addis Ababa, Ethiopia.

Kebede, B., Soromessa, T. \& Kelbessa, E. (2012). Endemic Plant Species Composition and their Status in Gedo Dry Evergreen Montane Forest, West Shewa Zone of Oromia National Regional State, Central Ethiopia. J. Recent Trends Biosci. 2(1): 82-84.

Kelbessa, E., Demissew, S., Woldu, Z. \& Edwards, S. (1992). Some threatened Endemic Plants of Ethiopia. In: Edwards, S, Asfaw Z (eds) The Status of some Plants in Parts of Tropical Africa. NAPRECA, No.2 Botany 2000: East and Central Africa. pp. 35-55.

Kent, M. \& Coker, P. (1992). Vegetation Description and Analysis: A Practical Approach. England: John Wiley and Sons Ltd.

Krebs, C. J. (1999). Ecological Methodology (2 ${ }^{\text {nd }}$ ed). Addison Wesley Longman, inc. Menlo Park, California. 454 pp.

Lemenih, M. \& Teketay, D. (2006). Changes in Soil Seed Bank Composition and Density following Deforestation and subsequent Cultivation of Dry Afromontane Forest in Ethiopia. J. Trop. Ecol. 47: 1-12.

Lemenih, M., Olsson, M. \& Karltun, E. (2004). Comparison of Soil attributes under Cupressus lusitanica and Eucalyptus saligna established on abandoned farmlands with continuously cropped farmland sand natural forest in Ethiopia, Forest Ecology and Management. 195, 57-67.

Lemenih, M. (2004). Effects of Land Use Changes on Soil Quality and Native Flora Degradation and Restoration in the Highlands of Ethiopia: Implications for sustainable land management, Doctoral Dissertation. Swedish University of Agricultural Sciences, Uppsala. 
Ma, M. (2006). Plant species diversity of buffer zones in agricultural landscapes: in search of determinants from the local to regional scale. $41 \mathrm{pp}$.

Magurran, A. E. (2004). Measuring Biological Diversity. Malden and Oxford: Blackwell Publishing.

Nikiema, A. (2005). Woody Species Composition of Sudan Savanna Parklands in relation to Rural Land Use Gradients in Burkina Faso. PhD dissertation. Wageningen University, Wageningen.

Oumer Ejero. (2009). Community Perception of on Farm Trees and Adjacent Natural Forest Status under Participatory Management: Dodola District, Ethiopia. MSc Thesis. Hawassa University, Wondo Genet College of Forestry and Natural Resources, Ethiopia

Power, A. \& Flecker, A. ( 2001). Agro-ecosystems and Biodiversity. Smithsonian Migratory Bird Centre. http://natzoo.si.edu/smbc/Research/Caca/power.htm Accessed on 20 July 2005.

Sanchez, P. A., Buresh, R.J. \& Leakey, R. R. B. (1997). Trees, soils, and food security. Phil. $\quad$ Trans. $\quad$ R. Soc. Lond. B. 352: 949-961.

Sayer, A. J., Harcourt, S. C. \& Collins, M. N. (1992). The Conservation Atlas of Tropical Forests in Africa. IUCN, Cambridge, UK, 288 pp.

Schelas, J.\& Greenberg, R. (1996). Forest Patches in Tropical Landscapes, Islands press, Washington D. C.

Senbeta, F. \& Denich, M. (2006). Effects of wild coffee Management on Species Diversity in the Afromontane rain Forests of Ethiopia, Forest Ecology and Management.232: 68-74.

Shibru, T. \& Martha, G. (1995). Biodiversity Management in Ethiopia. Regional Workshop on Biodiversity Management in Africa: Creating National Systems of Conservation and Innovation, $52 \mathrm{pp}$.

Tolera, M., Asfaw, Z., Lemenih, M. \& Karltun, E. (2008). Woody species Diversity in a Changing Landscape in the South-central Highlands of Ethiopia. Agriculture, Ecosystems and Environment. 128: 52-58.

Tolera, M. (2006). Woody Species Diversity of Agricultural Landscapes in Nagelle Arsi District, Ethiopia: Implications for Biodiversity Conservation, MSc Thesis, Hawassa University, Wondo Genet College of Forestry, Wondo Genet, Ethiopia.

\section{Tables}

Table 1. Diversity indices of woody species (trees/shrubs) in natural forest and crop fields, Nagelle Arsi, Ethiopia.

\begin{tabular}{lllll}
\hline $\begin{array}{l}\text { Land use } \\
\text { type }\end{array}$ & $\begin{array}{l}\text { Shannon } \\
\text { diversity } \\
\text { index (H') }\end{array}$ & $\begin{array}{l}\text { Simpson diversity index } \\
(1-\mathrm{D})\end{array}$ & $\begin{array}{l}\text { Species } \\
\text { Evenness } \\
(\mathrm{J})\end{array}$ & $\begin{array}{l}\text { Fisher } \\
\text { Alpha } \\
(\alpha)\end{array}$ \\
\hline Crop fields & $2.117^{\mathrm{a}}$ & 0.837 & 0.709 & 7.247 \\
Natural forest & $2.414^{\mathrm{b}}$ & 0.882 & 0.671 & 7.337 \\
\hline
\end{tabular}

Means of diversity index followed by different letters are significantly different $(\mathrm{P}<0.05)$. 
Table 2. Density, Frequency and Importance Value Index (IVI) of woody species in Mount Duro Natural Forest and Crop Field in Nagelle Arsi Disrict, Oromiae, Ethiopia.

\begin{tabular}{|c|c|c|c|c|c|c|}
\hline \multirow[b]{2}{*}{ Woody Species } & \multicolumn{3}{|l|}{ Natural Forest } & \multicolumn{2}{|l|}{ Crop Field } & \multirow[b]{2}{*}{ IVI } \\
\hline & $\begin{array}{l}\text { Density } \\
\text { (Number/ha) }\end{array}$ & $\begin{array}{l}\text { Freq } \\
(\%)\end{array}$ & IVI & $\begin{array}{l}\text { Density } \\
\text { (Number/ha) }\end{array}$ & $\begin{array}{l}\text { Freq } \\
(\%)\end{array}$ & \\
\hline Acacia seyal & 0.0 & 0.0 & 0.0 & 0.4 & 11.9 & 8.8 \\
\hline Albiza gummifera & 0.0 & 0.0 & 0.0 & 0.2 & 7.1 & 5.8 \\
\hline Allophylus abyssinicus & 7.1 & 16.7 & 2.9 & 0.1 & 9.5 & 4.9 \\
\hline Apodytes dimidiata & 5.4 & 14.3 & 2.6 & 0.1 & 2.4 & 1.5 \\
\hline Bersama abyssinica & 100.6 & 88.1 & 22.6 & 0.3 & 7.1 & 5.3 \\
\hline Buddleja polystachya & 0.0 & 0.0 & 0.0 & 0.1 & 4.8 & 2.3 \\
\hline Calpurnia aurea & 1.8 & 9.5 & 1.2 & 0.1 & 4.8 & 2.3 \\
\hline Canthium oligocarpum & 1.2 & 4.8 & 0.6 & 0.0 & 0.0 & 0.0 \\
\hline Carissa spinarum & 0.6 & 2.4 & 0.3 & 0.0 & 0.0 & 0.0 \\
\hline Celtis africana & 2.4 & 9.5 & 2.0 & 0.4 & 14.3 & 9.9 \\
\hline Clematis longicauda & 7.1 & 0.0 & 2.5 & 0.0 & 0.0 & 0.0 \\
\hline Croton machrostachyus & 204.2 & 90.5 & 52.8 & 4.5 & 83.3 & 91.1 \\
\hline Dovyalis abyssinica & 4.2 & 16.7 & 1.6 & 0.0 & 0.0 & 0.0 \\
\hline Dregea schimperi & 3.0 & 11.9 & 1.6 & 0.0 & 0.0 & 0.0 \\
\hline Ekebergia capensis & 2.4 & 7.1 & 1.0 & 0.2 & 7.1 & 9.3 \\
\hline Erythrina brucei & 0.0 & 0.0 & 0.0 & 0.8 & 14.3 & 13.6 \\
\hline Euclea divinorum & 6.5 & 14.3 & 2.3 & 0.0 & 0.0 & 0.0 \\
\hline Fagaropsis angolensis & 7.1 & 11.9 & 2.1 & 0.0 & 0.0 & 0.0 \\
\hline Ficus sur & 0.5 & 11.9 & 1.3 & 0.8 & 23.8 & 11.7 \\
\hline Flacourtia indica & 0.0 & 0.0 & 0.0 & 0.1 & 7.1 & 3.9 \\
\hline Hagenia abyssinica & 0.6 & 2.4 & 0.4 & 0.0 & 0.0 & 0.0 \\
\hline Hibiscus micranthus & 0.6 & 2.4 & 0.3 & 0.0 & 0.0 & 0.0 \\
\hline Juniperus procera & 4.2 & 7.1 & 13.6 & 0.1 & 4.8 & 2.7 \\
\hline Maesa lanceolata & 120.8 & 61.9 & 22.2 & 0.1 & 4.8 & 2.3 \\
\hline Maytenus sp. & 60.7 & 66.7 & 16.2 & 0.0 & 0.0 & 0.0 \\
\hline Mikaniopsis clematoides & 7.7 & 14.3 & 2.3 & 0.0 & 0.0 & 30.4 \\
\hline Millettia ferruginea & 1.2 & 4.8 & 1.1 & 0.0 & 2.4 & 2.0 \\
\hline Myrsine melanophloeos & 1.2 & 4.8 & 0.6 & 0.0 & 0.0 & 0.0 \\
\hline Nuxia congesta & 1.2 & 7.1 & 1.0 & 0.0 & 2.4 & 1.2 \\
\hline Olea capensis & 0.0 & 0.0 & 0.0 & 0.0 & 2.4 & 1.5 \\
\hline Olea europaea subsp. & 0.0 & 0.0 & 0.0 & 0.0 & 2.4 & 1.5 \\
\hline \multicolumn{7}{|l|}{ Cuspidata } \\
\hline Pentas sp. & 1.2 & 4.8 & 0.6 & 0.0 & 0.0 & 0.0 \\
\hline Periploca linearifolia & 6.0 & 19.0 & 2.6 & 0.0 & 0.0 & 0.0 \\
\hline Phytolacca dodecandra & 1.8 & 4.8 & 0.6 & 0.0 & 0.0 & 0.0 \\
\hline Podocarpus falcatus & 96.4 & 69.0 & 57.0 & 1.9 & 33.3 & 53.6 \\
\hline Polyscias fulva & 26.2 & 35.7 & 6.4 & 0.0 & 0.0 & 0.0 \\
\hline Prunas africana & 3.6 & 4.8 & 2.1 & 0.0 & 0.0 & 0.0 \\
\hline Ricinus communis & 1.2 & 2.4 & 0.4 & 0.0 & 0.0 & 0.0 \\
\hline Rubus apetalus & 10.1 & 38.1 & 5.0 & 0.0 & 0.0 & 0.0 \\
\hline Rumex nervosus & 3.6 & 11.9 & 2.2 & 0.0 & 0.0 & 0.0 \\
\hline Schefflera abyssinica & 0.6 & 2.4 & 2.3 & 0.0 & 2.4 & 3.6 \\
\hline Teclea nobilis. & 61.9 & 61.9 & 16.5 & 0.1 & 4.8 & 2.6 \\
\hline Unidenitied sp2 & 1.0 & 28.6 & 0.9 & 0.2 & 2.4 & 0.0 \\
\hline Unidentified sp.1 (Hadhooftu) & 1.8 & 7.1 & 0.3 & 0.0 & 0.0 & 0.0 \\
\hline $\begin{array}{l}\text { Unidentified sp. } 3 \text { (Haadha } \\
\text { mannee) }\end{array}$ & 0.6 & 2.4 & 0.3 & 0.0 & 0.0 & 0.0 \\
\hline Urera hypselodendron & 13.1 & 35.7 & 5.2 & 0.0 & 2.4 & 1.1 \\
\hline Vangueria madagascariensis & 49.4 & 59.5 & 11.3 & 0.0 & 2.4 & 1.1 \\
\hline Vernonia amygdalina & 0.0 & 0.0 & 0.0 & 0.8 & 23.8 & 14.5 \\
\hline Vernonia myriantha & 190.5 & 95.2 & 31.0 & 1.0 & 11.9 & 11.7 \\
\hline
\end{tabular}




\section{Figures}
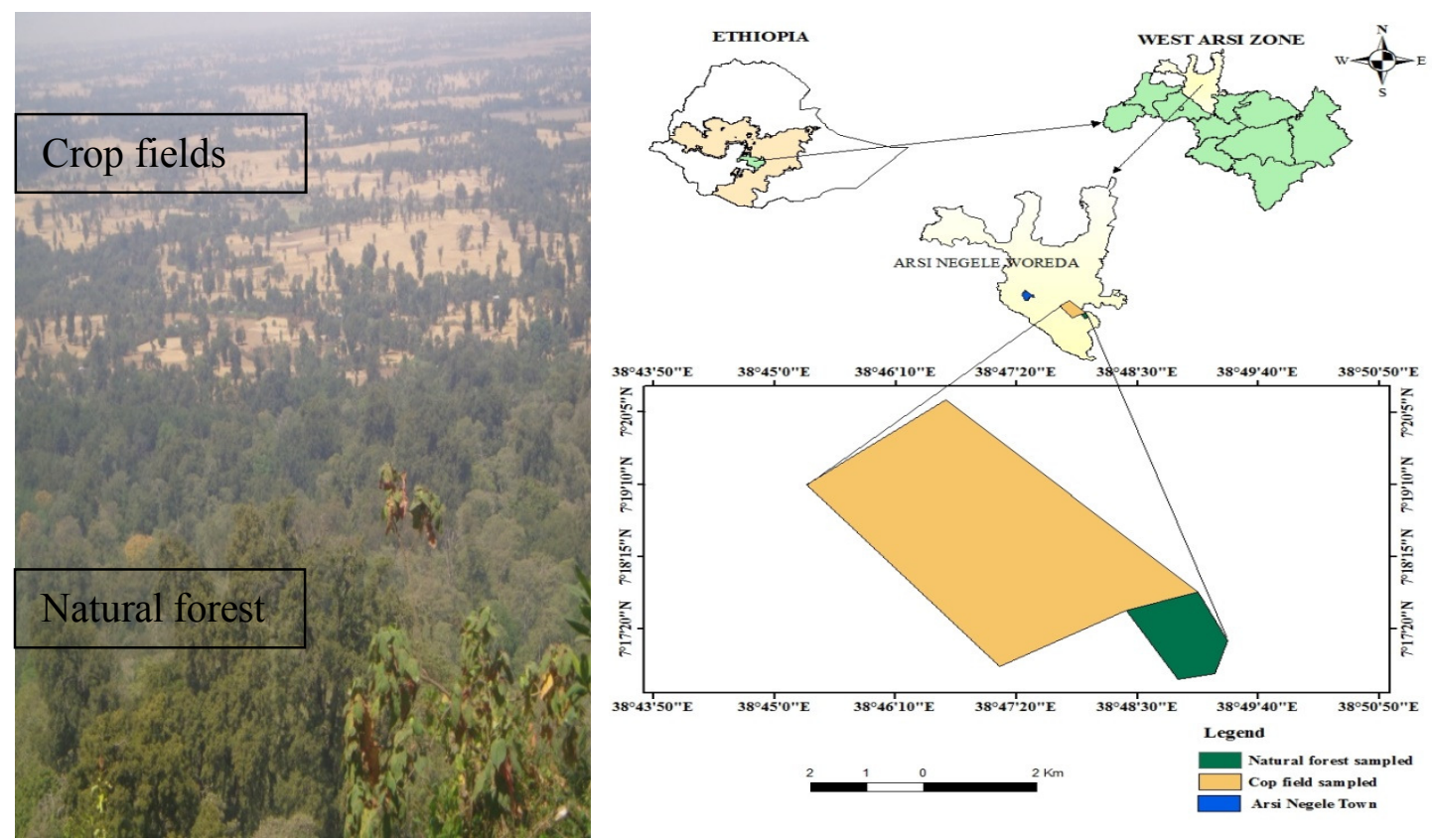

Figure 1. Map of study area in Nagelle Arsi District, West Arsi, Oromia, Ethiopia.

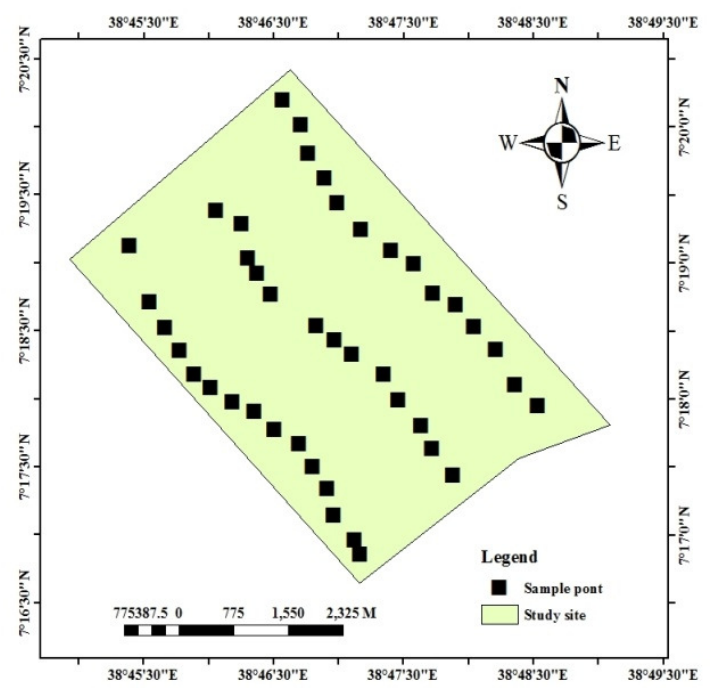

Figure 2 (a). Layout of vegetation data collection ample plots in natural forest of Mount Duro, Nagelle Arsi District, West Arsi, Oromia, Ethiopia. 


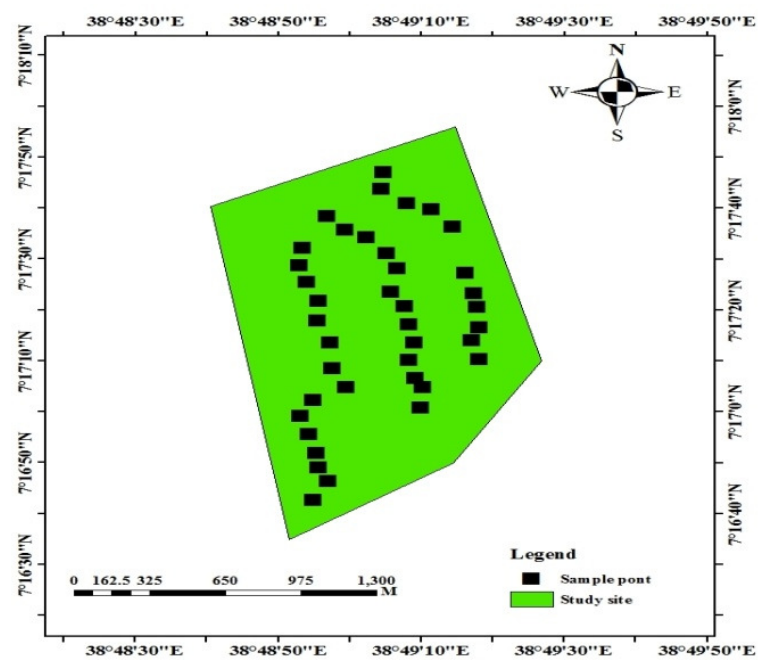

Figure 2(b). Layout of vegetation data sample plots in crop field, Nagelle Arsi, West Arsi, Oromia, Ethiopia.

Appendix 1. List of Species Documented during this study in both Natural Forest and Crop Fields in Nagelle Arsi District, West Arsi Zone, Oromia, Ethiopia.

\begin{tabular}{|c|c|c|c|c|}
\hline \multirow[t]{2}{*}{ Scientific Name } & \multirow[t]{2}{*}{ Family } & \multirow{2}{*}{$\begin{array}{l}\text { Vernacular Name } \\
\text { (Afaan Oromoo) }\end{array}$} & \multicolumn{2}{|c|}{ Encountered in: } \\
\hline & & & $\begin{array}{l}\text { Crop } \\
\text { Field }\end{array}$ & $\begin{array}{l}\text { Natural } \\
\text { Forest }\end{array}$ \\
\hline $\begin{array}{l}\text { Acacia seyal Del } \\
\text { Albiza gummifera (J.F.Gmel.) }\end{array}$ & Fabaceae & Waaccuu & 1 & 0 \\
\hline $\begin{array}{l}\text { C.A.S.M. } \\
\text { Allophylus abyssinicus (Hochst.) }\end{array}$ & Fabaceae & Muka Arbaa & 1 & 0 \\
\hline $\begin{array}{l}\text { Radlk. } \\
\text { Apodytes dimidiata E. Mey. ex }\end{array}$ & Sapindaceae & Hirqammuu & 1 & 1 \\
\hline Arn. & Icacinaceae & Odaa baddaa & 1 & 1 \\
\hline Bersama abyssinica Fresen. & Melianthaceae & Waraqqaa & 1 & 1 \\
\hline Buddleja polystachya Fresen. & Loganiaceae & Adaaddii & 1 & 0 \\
\hline Calpurnia aurea (Ait.) Benth. & Fabaceae & Ceekataa & 1 & 1 \\
\hline Canthium oligocarpum Hiern & Rubiaceae & Xiilloo & 0 & 1 \\
\hline Carissa spinarum $\mathrm{L}$. & Apocynaceae & Agamsa & 0 & 1 \\
\hline Celtis africana Burm. F & Ulmaceae & Amallaqaa & 1 & 1 \\
\hline Clematis longicauda & Ranunculaceae & Ciroontaa & 0 & 1 \\
\hline $\begin{array}{l}\text { Croton machrostachyus Del. } \\
\text { Dovyalis abyssinica (A. Rich.) }\end{array}$ & Euphorbiaceae & Bakkanniisaa & 1 & 1 \\
\hline $\begin{array}{l}\text { Warb. } \\
\text { Dregea schimperi (Decne.) }\end{array}$ & Flacourtiaceae & Qamoo & 0 & 1 \\
\hline Bullock & Asclepiadaceae & Gaalee dikii & 0 & 1 \\
\hline Ekebergia capensis Sparrm. & Meliaceae & Onoonnuu & 1 & 1 \\
\hline Erythrina brucei schweinf. & Fabaceae & Weleenaa & 1 & 0 \\
\hline $\begin{array}{l}\text { Euclea divinorum Hiern } \\
\text { Fagaropsis angolensis (Engl.) }\end{array}$ & Ebenaceae & Mi'eessaa & 0 & 1 \\
\hline Dale & Rutaceae & Qarcaccee & 0 & 1 \\
\hline $\begin{array}{l}\text { Ficus sur Forssk. } \\
\text { Flacourtia indica (Burm.f) J }\end{array}$ & Moraceae & Odaa nyaataa & 1 & 1 \\
\hline $\begin{array}{l}\text { Merr. } \\
\text { Hagenia abyssinica (Bruce) J.F. }\end{array}$ & Flacourtiaceae & Hudhaa & 1 & 0 \\
\hline Gmel. & Rosaceae & Heexoo & 0 & 1 \\
\hline Hibiscus micranthus L. $f$. & Malvaceae & Incinnii & 0 & 1 \\
\hline Juniperus procera Endl & Cupressaceae & Hindheessaa & 1 & 1 \\
\hline Maesa lanceolata Forssk. & Myrsinaceae & Abbayyii & 1 & 1 \\
\hline Maytenus sp. & Celestraceae & Kombolcha & 0 & 1 \\
\hline $\begin{array}{l}\text { Mikaniopsis clematoides (Sch. } \\
\text { Bip. ex A. Rich.) Milne-Redh. }\end{array}$ & Asteraceae & Gaalee fiitii/korma & 0 & 1 \\
\hline
\end{tabular}




\begin{tabular}{|c|c|c|c|c|}
\hline \multirow[t]{2}{*}{ Scientific Name } & \multirow[t]{2}{*}{ Family } & \multirow{2}{*}{$\begin{array}{l}\text { Vernacular Name } \\
\text { (Afaan Oromoo) }\end{array}$} & \multicolumn{2}{|c|}{ Encountered in: } \\
\hline & & & $\begin{array}{l}\text { Crop } \\
\text { Field }\end{array}$ & $\begin{array}{l}\text { Natural } \\
\text { Forest }\end{array}$ \\
\hline \multicolumn{5}{|l|}{ Millettia ferruginea (Ho\&Hst.) } \\
\hline Bak & Fabaceae & Dhaadhaatuu & 1 & 1 \\
\hline Myrsine melanophloeos (L.) R. & & & & \\
\hline $\mathrm{Br}$. & Myrsinaceae & Unidentified & 0 & 1 \\
\hline Nuxia congesta R.Br. ex Fresen. & Loganiaceae & Buchaanaa & 1 & 1 \\
\hline Olea capensis & Oleaceae & Seegeda & 1 & 0 \\
\hline \multicolumn{5}{|l|}{ Olea europaea } \\
\hline \multicolumn{5}{|l|}{ L.subsp.cuspidata } \\
\hline (Wall.exG.Don).CF. & Oleaceae & Ejersa & 1 & 0 \\
\hline Pentas sp. & Rubiaceae & Unidentified & 0 & 1 \\
\hline \multicolumn{5}{|l|}{ Periploca linearifolia Quart.- } \\
\hline Dill. \& A. Rich. & Asclepiadaceae & Gaalee Aannannoo & 0 & 1 \\
\hline $\begin{array}{l}\text { Phytolacca dodecandra } \mathrm{L} \text { 'Herit. } \\
\text { Podocarpus falcatus (Thunb.) }\end{array}$ & Phytolaccaceae & Andoodee & 0 & 1 \\
\hline C.N. & Podocarpaceae & Birbirsa & 1 & 1 \\
\hline Polyscias fulva (Hiern) Harms & Araliaceae & Warqichoo jaldeessaa & 0 & 1 \\
\hline Prunus africana(Hook.f.) Kalkm & Rosaceae & Sukkee & 1 & 1 \\
\hline Ricinus communis $L$. & Euphorbiaceae & Qobboo & 0 & 1 \\
\hline Rubus apetalus Poir. & Rosaceae & Goraa & 0 & 1 \\
\hline Rumex nervosus Vahl & Polygonaceae & Dhangaggoo & 0 & 1 \\
\hline \multicolumn{5}{|l|}{ Schefflera abyssinica } \\
\hline (Hochst.ex.A.Rich.) & Araliaceae & Gatamee & 1 & 1 \\
\hline $\begin{array}{l}\text { Teclea nobilis Del. } \\
\text { Urera hvpselodendron (A Rich) }\end{array}$ & Rutaceae & Hadheessaa & 1 & 1 \\
\hline Wedd. & Urticaceae & Gaalee haliillaa & 1 & 1 \\
\hline \multicolumn{5}{|l|}{$\begin{array}{l}\text { Wead. } \\
\text { Vangueria madagascariensis }\end{array}$} \\
\hline Gmel. & Rubiaceae & Gaalloo & 1 & 1 \\
\hline Vernonia amygdalina Del. & Asteraceae & Eebicha & 1 & 0 \\
\hline Vernonia myriantha Hook. J. & Asteraceae & Reejiii & 1 & 1 \\
\hline Unidentified & Unidentified & Haadhamanee & 0 & 1 \\
\hline Unidentified & Unidentified & Ancootee & 0 & 1 \\
\hline Unidentified & Unidentified & Hadhooftuu & 0 & 1 \\
\hline
\end{tabular}

